\title{
ULOGA NORMATIVNE BAZE PREDMETNIH ODREDNICA NACIONALNE I SVEUČILIŠNE KNJIŽNICE U ZAGREBU U KONTROLI I RAZMJENI PODATAKA U BIBLIOGRAFSKOM OKRUŽENJU
}

\author{
THE ROLE OF THE NATIONAL AND UNIVERSITY \\ LIBRARY SUBJECT HEADINGS AUTHORITY DATABASE IN \\ BIBLIOGRAPHIC CONTROL AND DATA EXCHANGE WITHIN \\ THE LIBRARY ENVIRONMENT
}

Suzana Dimovski

Nacionalna i sveučilišna knjižnica u Zagrebu

sdimovski@nsk.hr

Katarina Tuškan

Nacionalna i sveučilišna knjižnica u Zagrebu

ktuskan@nsk.hr

UDK / UDC 025.3

Stručni rad / Professional paper

Primljeno / Received: 31. 3. 2018.

Prihvaćeno / Accepted: 12. 6. 2018.

\section{Sažetak}

Cilj. U radu se raspravlja o važnosti normativne baze predmetnih odrednica u Nacionalnoj i sveučilišnoj knjižnici u Zagrebu kao jedinstvene baze koja putem standardiziranih zapisa omogućava jednoznačnu primjenu u bibliografskim zapisima. Sustavnim praćenjem razvoja formata MARC 21, inkorporiranje novih identifikatora zapisa u sustav Aleph doprinosi osuvremenjivanju normativnih zapisa, kvalitetnijoj bibliografskoj kontroli i razmjeni podataka u knjižničnom okruženju.

Vjesnik bibliotekara Hrvatske 61, 1(2018), 509-529

ISSN 0507-1925

(C) VBH 2018. 
Pristup/metodologija/dizajn. Kroz primjere dobre prakse u NSK-u pokazali smo kako kontrola nad sustavom predmetnih odrednica u normativnoj bazi podataka utječe na održavanje bibliografske baze podataka.

Rezultati. Jedan od načina održavanja kvalitete normativne baze podataka jest sustavni redakcijski nadzor. Ispravljanje zapisa u NSK-u je povjereno katalogizatorima za manji broj zapisa te ključnim i sistemskim knjižničarima za izmjene većeg broja zapisa globalnim izmjenama putem Sustava za podršku.

Originalnost/vrijednost. S obzirom na to da o ovoj temi nema dovoljno radova, a nacionalni pravilnik za predmetno označivanje još nije objavljen, rad će biti koristan svima koji se bave održavanjem predmetnog kataloga.

Ključne riječi: bibliografska baza podataka, Normativna baza predmetnih odrednica Nacionalne i sveučilišne knjižnice, normativna kontrola, sustavni redakcijski nadzor, Sustav za podršku

\section{Abstract}

Purpose. The paper discusses the importance of the Subject Authority Database of the National and University Library (NSK) in Zagreb as a unique database which through standardized records enables unambiguous application in bibliographic records. Systematic monitoring of the development of the MARC 21 format and the incorporation of new record identifiers into the Aleph system contributes to the modernization of authority records, better bibliographic control and data exchange within the library environment.

Approach/methodology/design. Through examples of good practice of the NSK, this paper shows how control over the system of subject headings carried out in the authority database, affects the maintenance of bibliographic databases.

Findings. Systematic editorial control is one of the quality control mechanisms of the authority database. In the case of a smaller number of records, corrections are entrusted to catalogers, but in the case of a larger number, key librarians and system librarians modify records through global changes in collaboration with the technical support system.

Originality/value. This paper will be of use to all who work on maintenance of subject catalogues because there is not enough research on this topic, and national guidelines for subject indexing have not yet been published.

Keywords: Authority control, bibliographic database, National and University Library Subject Headings Authority Database, Support system, Systematic editorial control 


\section{Uvod}

Ovim radom željeli smo istaknuti važnost Normativne baze predmetnih odrednica u Nacionalnoj i sveučilišnoj knjižnici u Zagrebu. Njezina važnost ogleda se u tome što se standardiziranim predmetnim odrednicama omogućava jednoznačna primjena u bibliografskim zapisima. Kvalitetnim uputno-informativnim sustavom i ostalim elementima normativnog zapisa olakšava se rad i smanjuje mogućnost pogreške. Pomoću kontroliranog rječnika koji sadrži termine za indeksiranje i sintaktička pravila može se izdvojiti više indeksiranih polja kao pristupnica u pretraživanju dokumenata. Kontroliranim jezikom predmetnih odrednica olakšava se pretraživanje i pronalaženje informacija po predmetu jer se isti ili slični sadržaji okupljaju pod istom odrednicom. Zbog velike produkcije zapisa potreban je trajan nadzor nad sustavom predmetnih odrednica. $U$ radu će biti prikazana praksa redakcijskog nadzora u normativnoj bazi u Nacionalnoj i sveučilišnoj knjižnici u Zagrebu.

\section{Razvoj predmetnog sustava Nacionalne i sveučilišne knjižnice u Zagrebu}

Sustav predmetnih odrednica u Nacionalnoj i sveučilišnoj knjižnici u Zagrebu posljednjih je godina doživio velike transformacije koje su odraz velikih tehnoloških promjena, razvoja formata MARC 21, IFLA-inih preporuka o nužnosti promjena za pojednostavljenje katalogizacije i konzistentnosti strukture podataka.

Izgradnja predmetnog sustava Nacionalne i sveučilišne knjižnice u Zagrebu počela je normiranjem odrednica najprije $u$ formatu UNIMARC i knjižničnom programu CROLIST, preko formata MARC 21 i knjižničnog programa Voyager, do programa Aleph ${ }^{1}$ koji je trenutno u upotrebi.

Stvaranje normativne baze predmetnih odrednica u Nacionalnoj i sveučilišnoj knjižnici u Zagrebu započelo je 1997. godine. Od tada su se publikacije počele predmetno označivati normiranim predmetnim odrednicama. Zbog velikog broja nestrukturiranih odrednica nastalih zbog nedostatka pisanih pravila moralo se započeti s revizijom predmetnog kataloga. Primjena Pravilnika za predmetni kata$\log ^{2}$ započela je 2004. godine, a primjena internog dokumenta Izrada predmetnog kataloga u NSK 2005 . godine. Njihovim korištenjem riješila su se pitanja izrade odrednica, uputno-informativni sustav i sintaksa odrednica. Ipak, nedostajale su upute za izradu i korištenje pojedinih odrednica kao sastavni dio normativnog

\footnotetext{
Knjižnični program Aleph u Nacionalnoj i sveučilišnoj knjižnici trenutno se nadograđuje na verziju 22.

2 Štrbac, D.; M. Vujić. Pravilnik za predmetni katalog. Zagreb: Knjižnice grada Zagreba, 2004.

3 Izrada predmetnog kataloga u Nacionalnoj i sveučilišnoj knjižnici u Zagrebu. Zagreb: Nacionalna i sveučilišna knjižnica u Zagrebu, 2005. (interni dokument).
} 
zapisa, kao što su tematske i formalne dodatne odrednice. Također su nedostajale upute o dvojezičnom povezivanju odrednica s ciljem razmjene u međunarodnom okruženju.

Problem s velikim brojem nestrukturiranih odrednica rješavao se postupno. Dodatne odrednice bez informativne vrijednosti bile su ukinute, a one sa sličnim sadržajem spojene su u jednu odrednicu. Kasnije, s promjenom knjižničnog sustava i promjenom formata, bilo je omogućeno normiranje dodatnih odrednica.

Pravilnici za predmetnu katalogizaciju temelje se na načelima za stvaranje predmetnih jezika pobrojanih u dokumentu Principles Underlying Subject Heading Languages, koji je izradila IFLA-ina Radna grupa za klasifikaciju i predmetno označivanje. Objedinjujući pristup formalnoj i predmetnoj katalogizaciji javlja se u recentnim međunarodnim dokumentima kao što je Izjava o međunarodnim kataložnim načelima iz 2009. ${ }^{4}$

Odlukom Stručnog vijeća Nacionalne i sveučilišne knjižnice 2009. godine odobren je rad na reviziji predmetnog kataloga i njegovu prilagođavanju modelu Library of Congress Subject Headings (LCSH) ${ }^{5}$. Model LCSH prihvaćen je kao međunarodni standard za predmetnu obradu zbog svoje dugogodišnje prakse, jasno postavljenih pravila za sintaksu predmetne odrednice i predmetnog niza te zbog uputa za korištenje vodećih i dodatnih odrednica.

Revizija oblikovanja predmetnih odrednica započela je 2010. godine, a 2011. godine započinje se s korištenjem Subject Headings manual (SHM). ${ }^{6}$ Revizija predmetnog sustava još uvijek nije završena. Revidiraju se ne samo vodeće i dodatne postojeće odrednice već i cijeli zapisi sa svim potrebnim elementima. Zapisi se nadopunjavaju klasifikacijskom oznakom, širim, užim ili srodnim pojmovima, napomenama, engleskom inačicom predmetne odrednice, poveznicom sa zapisima u LCSH-u i mrežnim izvorima, npr. s izdanjima Leksikografskog zavoda Miroslav Krleža.

U 2018. godini očekuje se objava novog Pravilnika za predmetni sustav, kao zajedničkog projekta Ministarstva kulture RH i Nacionalne i sveučilišne knjižnice u Zagrebu. Izrada pravilnika nametnula se kao prirodan slijed prethodno navedenih događaja. Detaljnim uputama, primjerima iz baze Nacionalne i sveučilišne knjižnice, kao i popisima odrednica, omogućit će se ujednačena predmetna obrada građe te izrada $i$ ispravci zapisa predmetnih odrednica u bibliografskoj i norma-

\footnotetext{
4 Izjava o Međunarodnim kataložnim načelima / prevela Mirna Willer. 2009. [citirano: 2018-0611]. Dostupno na: https://www.ifla.org/files/assets/cataloguing/icp/icp_2009-hr.pdf.

5 Library of Congress Subject Headings. 29th ed. Washington, D.C.: Library of Congress, Cataloging Distribution Service, 2006. [citirano: 2018-06-11]. Dostupno i na: http://id.loc.gov/authorities/subjects.html.

${ }^{6}$ Subject Headings manual (SHM ) [citirano: 2018-3-24]. Dostupno na: https://www.loc.gov/ aba/publications/FreeSHM/freeshmabout.html. Izvorno je zamišljen kao interni dokument, no kasnije radi jasne politike predmetne katalogizacije postaje alat i ostalim knjižnicama.
} 
tivnoj bazi podataka. Novim pravilnikom riješit će se mnoge poteškoće i otvorena pitanja na koja stari pravilnici nisu mogli dati odgovore. Knjižnice u Hrvatskoj predmetno bi katalogizirale svoju građu na temelju jedinstvenih pravila. Time bi se postigao ujednačen rad korištenjem standardizirane terminologije. Razmjena predmetnih odrednica između knjižnica u Republici Hrvatskoj bila bi olakšana primjenom jedinstvenog pravilnika za rad. On će obuhvatiti ne samo procedure i praksu već i politiku predmetne katalogizacije temeljene na međunarodnim standardima i smjernicama, prije svega na predmetnom sustavu Kongresne knjižnice (LCSH). Predmetni podaci kreirani u knjižničnom katalogu trebali bi se strukturirati kao otvoreni podaci u kontekstu povezanih podataka na semantičkom webu. Pritom je nesporna važnost normativne baze predmetnih odrednica u kontroli i razmjeni podataka u tom okruženju.

\section{Normativna baza predmetnih odrednica Nacionalne i sveučilišne knjižnice u Zagrebu}

Normativna baza u Nacionalnoj i sveučilišnoj knjižnici u Zagrebu predstavlja jedinstvenu bazu podataka koja sadrži normativne zapise za imena, predmetne odrednice i dodatne predmetne oznake potrebne za izradu složenih predmetnih odrednica. ${ }^{7}$ Ona je relacijska baza ${ }^{8}$ i nadređena je svim bibliografskim bazama koje ju koriste. Koristi ju veći broj visokoškolskih i znanstvenih knjižnica u nacionalnom knjižničnom informacijskom sustavu čiji se rad temelji na knjižničnom programu Aleph te formatu MARC 21.

Normativna baza predmetnih odrednica sadrži zapise predmetnih odrednica i dodatnih predmetnih odrednica te strukturirani uputni sustav i odgovarajuće napomene. Budući da ona izravno utječe na sustav predmetnih odrednica u bibliografskoj bazi, potrebna je njezina uspostava ne samo na lokalnoj ili regionalnoj već i na nacionalnoj razini. ${ }^{9}$ Ta je tema bila aktualna i mnogo ranije, što se vidi i u članku I. Kanič gdje se govori da je normativna baza temelj za oblikovanje nacionalnog sustava bibliografske kontrole, a u budućnosti i za povezivanje sustava na

\footnotetext{
7 Vujić, M. Pregledni zapisi u formatu MARC 21: upute za katalogizaciju. Zagreb: Nacionalna i sveučilišna knjižnica u Zagrebu, 2011.

8 Relacijske baze podataka zasnivaju se na relacijskim strukturama podataka u obliku međusobno povezanih tablica ili relacija. Usp. Osnove projektiranja baza podataka: priručnik za polaznike. Zagreb: Sveučilišni računalni centar, 2010. [citirano: 2018-05-18]. Dostupno na: http://www.srce. unizg.hr/files/srce/docs/edu/osnovni-tecajevi/d310_polaznik.pdf.

9 Strategija Nacionalne i sveučilišne knjižnice u Zagrebu: 2016.-2020. [citirano: 2018-06-11]. Dostupno na: http://www.nsk.hr/wp-content/uploads/2012/01/Strategija-NSK-2016.-2020..pdf. Osigurani su uvjeti za uspostavu nacionalne normativne baze podataka (za imena, predmetnice) u okruženju semantičkog weba. Predmetni podaci Knjižnice temelje se na predmetnom sustavu Kongresne knjižnice (LCSH) i povezuju se s leksikografskim natuknicama iz međunarodnih tezaurusa.
} 
međunarodnoj razini. ${ }^{10}$ Situacija bi bila jednostavnija ukoliko bi se knjižnice koristile istim pravilnikom za predmetnu katalogizaciju, imale isti knjižnični sustav i jedinstveni format za strojno čitljivo katalogiziranje. Predmetna obrada publikacija u knjižnicama bila bi ujednačena standardiziranim predmetnim odrednicama.

Nacionalnoj i sveučilišnoj knjižnici u Zagrebu dodijeljen je 2009. godine međunarodni kôd nskps od strane Network Development and MARC Standards Office, Library of Congress, koji označava Predmetni sustav Nacionalne i sveučilišne knjižnice u Zagrebu. Primjenom kôda nskps u bibliografskim zapisima potvrđuje se da su predmetne odrednice izrađene u skladu s pravilima predmetne katalogizacije.

\section{Primjer 1.650 7 \$a Mostovi \\ \$x Aerodinamika \\ \$2 nskps}

Osim kôda nskps, u normativnim zapisima koristi se kôd enskps ${ }^{11}$. On služi za izgradnju dvojezičnog hrvatsko-engleskog kontroliranog rječnika predmetnih odrednica, što je važno radi međunarodne razmjene podataka. Hrvatske i engleske oblike odrednica povezujemo unutar istog predmetnog sustava (nskps i enskps).

Primjer 2.150 \$a Mostovi

\$x Aerodinamika

\section{7 $\$$ a Bridges}

$\$ x$ Aerodynamics

\$2enskps

Sustavan rad nad normiranim predmetnim zapisima, u smislu izrade novih zapisa te dopuna i uređivanja starih zapisa, a u skladu s pravilima predmetne katalogizacije, omogućit će jednoznačnu primjenu u bibliografskim zapisima. Iz tog razloga zapisi moraju biti standardizirani, opremljeni napomenama o opsegu pojma i njegovu korištenju, iz kojih proizlazi oblikovanje i sintaksa predmetnih odrednica, odnosno redoslijed predmetnog niza.

\section{Normativna kontrola i kvaliteta zapisa}

Produkcija zapisa u normativnoj bazi vrlo je velika, što se vidi iz statistike Nacionalne i sveučilišne knjižnice u Zagrebu. ${ }^{12}$ Konzistentnost, jedinstvenost i do-

${ }_{10}$ Kanič, I. Normativna kontrola in normativne datoteke. // Knjižnica 34, 1/2, (1990), str. 5. [citirano: 2018-03-24]. Dostupno na: https://www.dlib.si/stream/URN:NBN:SI:DOC-OREGQFZ3/ cf06cdd7-b3f6-41c2-a685-05da77ea899d/PDF.

${ }^{11}$ Kratica enskps znači engleski_nacionalna i sveučilišna knjižnica_predmetni sustav.

12 Statistika NSK-a o broju zapisa pojedine kategorije prema stanju na dan 2. siječnja 2018. godine: od ukupno 565327 normativnih zapisa, 485176 je zapisa za osobno ime, 21309 za korporativna tijela, 24569 za opći pojam, 15140 za geografsko ime, 72 za žanr/oblik, 2237 za dodatne odrednice itd. 
sljednost odrednica postiže se normativnom kontrolom. ${ }^{13}$ Ona je nužna i predstavlja velik izazov, što se navodi i u članku I. Kanič gdje se ističe da je normativna kontrola stara koliko i katalozi, da je neophodna upravo zbog opsega i održavanja kataloga te da ima izravan utjecaj na njegovu kvalitetu. ${ }^{14}$

Kontrola nad sustavom predmetnih odrednica koja se vrši u normativnoj bazi podataka utječe na održavanje i kvalitetu bibliografske baze podataka. Radi veće učinkovitosti i kvalitete sustava važno je da zapisi u normativnoj bazi budu što potpuniji. To ovisi o više čimbenika: educiranosti katalogizatora u predmetnoj obradi, poznavanju struke i formata MARC 21, prihvaćanju pravilnika/uputa za rad, vještini pretraživanja baze podataka i informatičkoj podršci. Vodeći se načelom primjerenosti korisniku, knjižnice posebnu pažnju moraju posvetiti kvaliteti svojih podataka. Pronalaženjem literature u javno dostupnim katalozima (OPAC) krajnji korisnici mogu ocijeniti funkcionalnost sučelja i pretraživača te kvalitetu podataka.

Prema Branki Badovinac ,svrha kvalitete zapisa prvenstveno je zadovoljiti potrebe krajnjih korisnika, u skladu s općim načelima, standardizacijom i razmjenom podataka u lokalnom i međunarodnom okruženju“ ${ }^{15}$

Knjižnice iz pragmatičnih razloga trebaju održavati kvalitetu zapisa, što će u konačnici značiti i jednostavnu razmjenu podataka na svim razinama.

Mjerenje kvalitete zapisa obuhvaća količinu podataka u zapisu i postotak grešaka koji ovisi o standardima prihvaćenih od strane ustanove koja izrađuje zapise. ${ }^{16}$

Reducirani podaci u normativnom zapisu automatski znače manju mogućnost pretraživanja korisnika putem indeksiranih polja jer nedostaju elementi zapisa (npr. sinonimi, kvazisinonimi, homonimi, srodni pojmovi, engleske poveznice).

Normativna baza dinamična je i u njoj se promjene odvijaju svakodnevno. Kvaliteta zapisa ovisit će o spremnosti katalogizatora da prati razvoj stručne terminologije te osuvremenjuje zastarjele pojmove. Mora pratiti razvoj formata kako bi inkorporiranjem novih polja u zapisima s novim sadržajima povećavao mogućnost kvalitetnog pretraživanja.

Standardi kvalitete mijenjali su se s razvojem tehnologije, što možemo vidjeti i u starijim radovima o bibliografskoj i normativnoj kontroli gdje autori govore o toleriranju pogrešaka u zapisima, ekonomičnosti i fleksibilnosti u radu itd. Tho-

13 Označava skup postupaka ažuriranja normativne baze i održavanja konzistentnosti oblika odrednica u bibliografskim zapisima njihovom provjerom u normativnoj bazi.

14 Kanič, I. Nav. dj., str. 2.

15 Badovinac, B. Izhodišča za proučevanje kakovosti podatkov v bibliografskih in normativnih zapisih: kakovost podatkov v kontekstu in raziskovalne usmeritvev katalogizaciji. // Knjižnica 61, 1-2 (2017), str. 122.

${ }^{16}$ Hider, P.; K. Tan. Constructing record quality measures based on catalog use. // Cataloging and Classification Quarterly, 46, 4 (2008), 338-361. Citirano prema: Badovinac, B. Nav. dj., str. 137. 
mas ističe da je definicija kvalitete dinamična i da će ovisiti o potrebama korisnika. Standardi kvalitete mijenjali su se i u Kongresnoj knjižnici, pa je tako prema njihovim internim dokumentima za praćenje kvalitete iz 1979. godine postojala razlika između većih i manjih pogrešaka, pri čemu su se manje dopuštale. To je trajalo sve do 1985. godine, kada su sve pogreške bile izjednačene. One su se odnosile na pogreške u pristupnim točkama zapisa, a ne i na krive dijakritike, interpunkciju i sl. u nepristupnim točkama. ${ }^{17}$

U današnje vrijeme u praksi Nacionalne i sveučilišne knjižnice ne dopuštaju se nikakve pogreške u zapisima, a ukoliko se iz bilo kojeg razloga pojave, one se trebaju ispraviti.

Graham tvrdi da su kvaliteta zapisa i produktivnost djelatnika koji rade na obradi knjižnične građe u katalogizaciji obrnuto proporcionalne. ${ }^{18}$ Ističe da su važne dvije karakteristike, opseg i točnost, kao i da se radi ekonomičnosti trebaju smanjiti troškovi katalogizacije, npr. kod normativne kontrole, te da zapisi mogu biti „,siromašni“ čak i s pogreškama. ${ }^{19}$ Naravno da se s tom konstatacijom ne možemo složiti. Naprotiv, u interesu cijele knjižnične zajednice i krajnjeg korisnika jest kvalitetna baza podataka. Utrošeno vrijeme u izradi novih ili nadopunjavanju starih zapisa nije relevantan čimbenik ako se ostvari krajnji cilj - suvremen, točan, stabilan i konzistentan predmetni sustav.

Gregor i Mandel dodjeljivanje predmetnih odrednica smatraju subjektivnom kategorijom koja ovisi o obrazovanju i iskustvu predmetnog katalogizatora, a održavanje konzistentnosti i reviziju odrednica gledaju kao neekonomičan postupak za knjižnice. Stoga zagovaraju fleksibilnost u primjeni pravila za rad uz toleriranje manjih nedosljednosti u pojedinim područjima. ${ }^{20}$

Takva razmišljanja ne bi trebala biti primjenjiva u današnje vrijeme. Pravila za rad moraju se poštivati jer kršenjem načela narušavamo konzistentnost predmetnog sustava.

Rad u normativnoj bazi i normativnu kontrolu zorno su prikazuju Mugridge i Furniss, koji definiraju rad u normativnoj bazi kao intelektualni napor tijekom predmetne katalogizacije radi odabira odrednica koje će se koristiti u kataložnom zapisu. Normativnu kontrolu smatraju radom koji se odvija za vrijeme katalogiza-

\footnotetext{
17 Thomas, S. E. Quality in bibliographic control. // Library Trends 44, 3 (1996), 491-505. [citirano: 2018-03-24] Dostupno na: https://www.ideals.illinois.edu/bitstream/handle/2142/8039/ librarytrendsv44i3d_opt.pdf?sequence $=1$.

18 Graham, P. S. Quality in cataloging: making distinctions. // Journal of Academic Librarianship 16, 4 (1990), str. 213. [citirano: 2018-03-24]. Dostupno na: https://eric.ed.gov/?id=EJ416995.

19 Graham, P. S. Nav. dj., str. 217.

20 Gregor, D.; C. Mandel. Cataloging must change! // Library Journal 116, 6(1991), str. 42-47. [citirano: 2018-03-24]. Dostupno na: https://eric.ed.gov/?id=EJ424864.
} 
cije, ali i nakon nje, radi održavanja kataloga. ${ }^{21}$ Postupak predmetne katalogizaci$\mathrm{je}^{22}$ kompleksan je i skup te zahtijeva i vrijeme i znanje.

Normativnom kontrolom održava se predmetni katalog u Nacionalnoj i sveučilišnoj knjižnici u Zagrebu. Dosljednom primjenom pravila za predmetnu katalogizaciju preuzimaju se predmetne odrednice u bibliografskim zapisima.

\section{Održavanje normativne i bibliografske baze predmetnih odrednica}

Konzistentnost baze predmetnih odrednica, kvaliteta i interoperabilnost podataka u Nacionalnoj i sveučilišnoj knjižnici u Zagrebu održavaju se od 2016. godine sustavnim redakcijskim nadzorom. Redoviti izvještaji (tjedni, mjesečni) o uočenim nepravilnostima vezanim uz predmetni sustav u oblikovanju odrednica, tipografskim i pravopisnim pogreškama te pogreškama u primjeni formata MARC 21 (kriva polja, potpolja, indikatori...) doprinose uređenju i održavanju stabilnosti baza.

Održavanje i osiguravanje funkcionalnosti baza podataka zahtjevan je postupak kojim se osigurava jednostavno pretraživanje, povezivanje, preuzimanje i prilagodba predmetnih odrednica te ispravljanje pogrešaka. Postupak zahtijeva pisane upute i procedure rada, planiranje, nadogradnju i nadzor nad podacima. Za održavanje baze predmetnih odrednica u Nacionalnoj i sveučilišnoj knjižnici u Zagrebu odgovorni su sami knjižničari i redaktori predmetnog sustava koji svojim svakodnevnim radom pregledavaju, uređuju i nadopunjavaju zapise. Podrška su u tome redaktori baze, ključni i sistemski knjižničari. Održavanje knjižničnog sustava ne može se zamisliti bez tehničke podrške sustava. ${ }^{23}$

U sljedećim potpoglavljima bit će sustavno prikazani postupci izrade predmetnih odrednica i vrste pogrešaka pri njihovoj izradi, zatim procesi ispravljanja predmetnih zapisa, dopune predmetnih odrednica i, na kraju, udio svih sudionika u redakcijskom nadzoru i tehničke podrške sustava za nadzor.

\subsection{Izrada normativnih zapisa predmetnih odrednica}

Postupak normiranja predmetnih odrednica vrlo je složen te zahtijeva vrijeme i znanje predmetnog katalogizatora. Potrebno je poznavati terminologiju područja za koje se obrađuje knjižnična građa, pravila o izgradnji odrednica, format MARC

\footnotetext{
21 Mugridge, R. L.; K. A. Furniss. Education for authority control: whose responsibility is it? // Cataloging \& Classification Quarterly 34, 1/2 (2002), 231-241. DOI: https://doi.org/10.1300/ $\mathrm{J} 104 \mathrm{v} 34 \mathrm{n} 0114$.

22 Postupak kojim se identificira tema (predmet) djela dodjeljivanjem predmetnih odrednica.

23 Sustav za podršku Nacionalne i sveučilišne knjižnice u Zagrebu osigurava stručnu, tehničku i administrativnu podršku radu zajedničkog informacijsko-knjižničnog sustava [citirano: 2018-0611]. Dostupno na: http://iks.nsk.hr/podrska.
} 
21 za normativne zapise i pretraživanje $u$ knjižničnom programu Aleph po svim parametrima.

Najprije se predmetnom analizom djela izdvajaju sve relevantne teme. Djelu se dodjeljuje onoliko odrednica koliko je potrebno da se izraze glavni predmeti djela. Nova predmetna odrednica oblikuje se ako predstavlja izdvojen pojam koji je moguće identificirati kada se prvi put pojavi u djelu koje se katalogizira. Oblikovanje predmetnih odrednica mora biti u skladu s deskriptivnim pravilima i pravilima za predmetnu katalogizaciju koja su u upotrebi. Postupkom validacije iz bibliografskog zapisa vrši se provjera predmetne odrednice u normativnoj bazi. Ukoliko se ustanovi da je nema, izrađuje se nova predmetna odrednica.

Normativni zapisi svrstani su u osam kategorija oznaka:

- Osobne oznake

- Korporativne oznake

- Oznake za stvarni naslov

- Geografske oznake

- Oznake za opći pojam

- Vremenske oznake

- Oznake za žanr/oblik

- Dodatne oznake.

Predmetna odrednica oblikuje se u normativnoj bazi odabirom predloška za određenu vrstu odrednice. Oblikuje se prema suvremenom hrvatskom jeziku, u prirodnom redoslijedu riječi. Odrednice mogu biti oblikovane istovjetno kao i u LCSH-u ili uz prilagodbu prirodnom jeziku.

- Odrednice u nskps-u ne oblikuju se u inverziji (osim geografske odrednice)

Primjer 3. Odrednica u LCSH-u

Chemistry, Inorganic
Odrednica u nskps-u

Anorganska kemija

- Značajan dio odrednica LCSH-a oblikovan je u prirodnom redoslijedu riječi kao i u našem katalogu.

Primjer 4. Odrednica u LCSH-u Croatian literature
Odrednica u nskps-u

Hrvatska književnost

- Dio odrednica semantički je sličan, a sintaktički odgovarajući.

Primjer 5.

NSK Shakespeare, William--Recepcija--Sjedinjene Američke Države

LCSH Shakespeare, William, 1564-1616--Appreciation--United States.

Obje su dodatne odrednice višenamjenske i dijele se geografski. 
- Sintaktičko i semantičko odstupanje

Dugogodišnja praksa NSK-a u nekim se slučajevima razlikuje od LCSH-ove prakse. Neki su pojmovi kao cjelina uži od onih korištenih u LCSH-u. Takav su slučaj pravci u književnosti i umjetnosti. U oba kataloga vodeća je (pristupna) odrednica uvijek pravac, ali je razlika u dodatnoj odrednici.

Složene odrednice tog tipa u NSK-u je potrebno normirati kao cjelinu jer dodatne odrednice koje se uz njih koriste nisu višenamjenske.
Primjer 6. Odrednica u nskps-u
Odrednica u LCSH-u
Romantizam --Umjetnost
Romanticism in art
Romantizam--Hrvatska književnost Romanticism--Croatia

\subsection{Pogreške i ispravke zapisa u normativnoj bazi predmetnih odrednica}

Pogreške nastale u normativnoj bazi mogu se podijeliti na sljedeće potkategorije:

- tipografsko-pravopisne pogreške

Primjer 7. Kralješnica $\rightarrow$ Kralježnica

- sintaktičke pogreške

Odrednica Zaštita okoliša u nskps-u vodeća je odrednica koja se po potrebi može dijeliti geografski. ${ }^{24} \mathrm{U}$ bibliografskoj bazi potrebno je izmijeniti sve geografske zapise koji imaju dodatnu odrednicu --Zaštita okoliša. Radi se o većem broju zapisa koji će biti izmijenjeni ručno ili globalno.

Primjer 8. 651 7 \$a Kaštelanski zaljev--Zaštita okoliša $\rightarrow$

6507 \$a Zaštita okoliša--Kaštelanski zaljev

- semantičke pogreške

Dodatna odrednica --Radiološka dijagnostika u bibliografskoj bazi javlja se u 122 zapisa. Pretraživanjem tih zapisa uočava se nepoklapanje sadržaja s dodatnom odrednicom. Naslovi zapisa zapravo govore o specifičnoj vrsti radiološke dijagnostike, npr. tomografiji, radiografiji, snimanju magnetskom rezonancom ili radionuklidnom snimanju, te ih jedino katalogizator može ručno izmijeniti.

${ }^{24}$ U polje 667 upisuje se interna napomena Dopuštena geografska podjela ili Nije dopuštena geografska podjela, kojom se određuje hoće li tematska dodatna odrednica biti ispred ili iza geografske, odnosno određuje se sintaksa predmetnog niza. 


\section{Primjer 9.}

Naslov: Usporedna analiza malignih tumora čeljusti višeslojnom kompjutoriziranom tomografijom (MSCT) i magnetskom rezonancijom (MR) : disertacija / Dijana Podoreški ; [mentor Ivan Krolo]. Zagreb : D. Podoreški, 2010.

Predmet: Čeljust--Karcinom--Radiološka dijagnostika

Nakon izmjene:

Čeljust--Karcinom--Tomografija

Čeljust--Karcinom--Snimanje magnetskom rezonancijom

- pogreške koje se događaju jer se odrednice, vodeće ili dodatne, ne povlače, tj. ne validiraju iz normativne baze

\section{Primjer 10. Nitrozo spojevi--Toksični učinci}

U bibliografskoj bazi uočen je zapis s neodgovarajućom dodatnom odrednicom koji će biti ručno izmijenjen, nakon čega će odrednica glasiti: Nitrozo spojevi-Toksikologija.

Dodatna odrednica --Toksični učinci jest neusvojeni pojam dodatne odrednice -Toksikologija (slika 1).

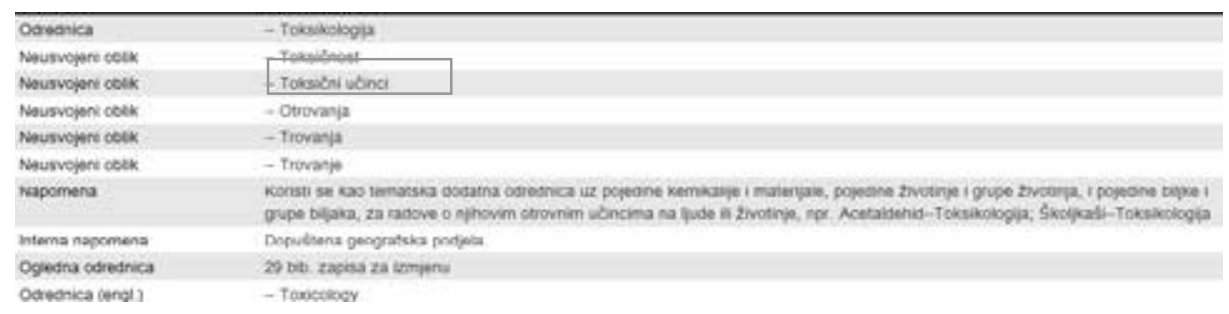

Slika 1. Normativni zapis dodatne odrednice Toksikologija

- izmjene oblika postojeće predmetne odrednice

Kod izmjene oblika postojećoj predmetnoj odrednici, u svim bibliografskim zapisima koji sadrže raniji oblik odrednice moraju se napraviti izmjene. U normativnom zapisu izmjenom usvojenog oblika odrednice u $1 \mathrm{XX}$ strojno se generira specijalno COR-polje (slika 2), polje knjižničnog sustava Aleph koje ima funkciju ažuriranja bibliografskih zapisa. Sustav COR-polje tretira kao neusvojeni termin te je poveznica s bibliografskim zapisom. ${ }^{25}$ Složene odrednice u bibliografskoj bazi (slika 3) ne mogu biti izmijenjene putem COR-polja. One će biti izmijenjene ručno ili putem globalnim izmjenama.

25 Exlibris. Aleph 23 user guide - authorities [citirano: 2018-5-17]. Dostupno na: https://knowledge.exlibrisgroup.com/Aleph/Product_Documentation/01_Version_23. 
Primjer 11. Vodeća odrednica Cestogradnja promijenila je oblik u Ceste--Projektiranje i izgradnja

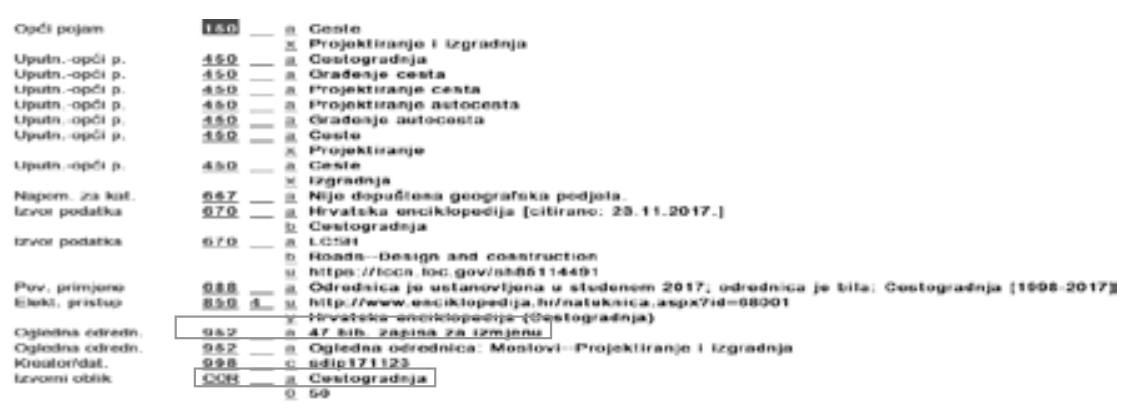

Slika 2. Izmijenjeni normativni zapis Cestogradnja

U održavanju predmetnih odrednica važnu ulogu ima lokalno polje 952. Ono ima dvojnu ulogu, a jedna je ta da se koristi za napomene u zapisima postojećih predmetnih odrednica ako je odrednica iz polja 1XX mijenjana (slika 2). Napomena sadrži podatak o broju bibliografskih zapisa koje treba izmijeniti. Može biti napisana kao trajna. Bilježi se u slučaju kada se treba izmijeniti veći broj zapisa, što se konstatira pretraživanjem bibliografske baze. Nakon obavljenih izmjena $u$ bibliografskim zapisima, bilo ručno ili strojno, globalnim ažuriranjem, u polje 952 normativnog zapisa treba upisati tekst: 0 bib. zapisa za izmjenu.

Pretraživanjem bibliografske baze pronađeno je 47 zapisa za izmjenu koji će se promijeniti globalnim ažuriranjem (slika 3).

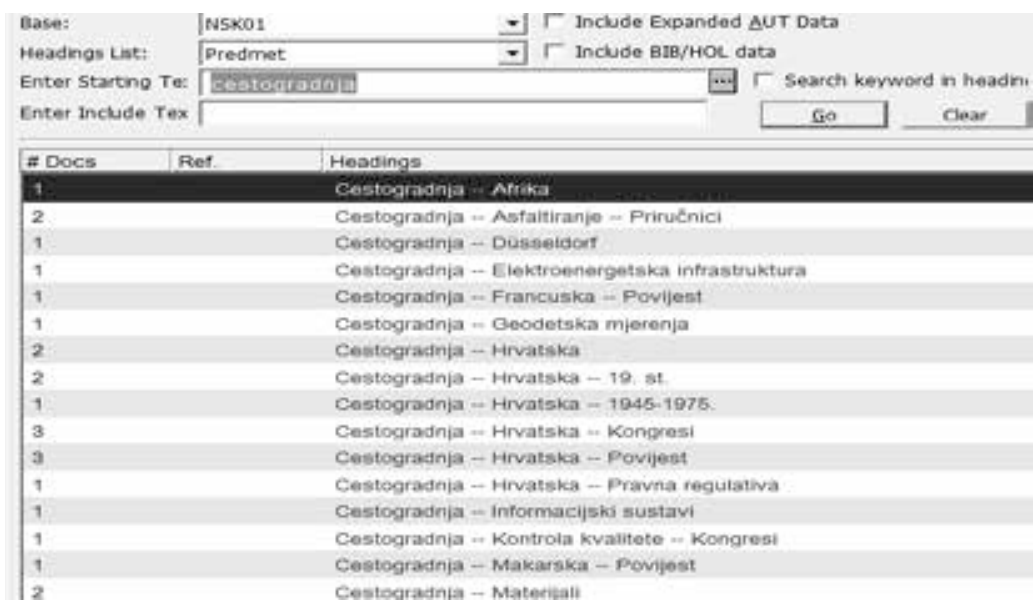

Slika 3. Predmetne odrednice Cestogradnja u bibliografskoj bazi 
- ispravke zapisa nakon oblikovanja novih predmetnih odrednica

Nakon izrade nove predmetne odrednice, pretražuje se bibliografska baza podataka kako bi se pronašli bibliografski zapisi za koje je nova odrednica odgovarajuća. U nekim će se slučajevima postojeća predmetna odrednica ili odrednice izbrisati, a nadomjestit će ih nova predmetna odrednica. U drugim će se slučajevima postojeće odrednice zadržati, a nova će se dodati.

Promjene oblika postojećih ili novih odrednica povjerene su katalogizatorima i redaktorima predmetnog kataloga radnog procesa sadržajne obrade.

\subsection{Sustavni redakcijski nadzor u Nacionalnoj i sveučilišnoj knjižnici}

Sustavnim redakcijskim nadzorom u Nacionalnoj i sveučilišnoj knjižnici omogućava se održavanje normativne i bibliografske baze predmetnih odrednica. Provodi se pomoću raznih alata: Sustav za podršku, SQL upiti, mjesečni popisi odrednica, popisi pogrešaka.

\subsubsection{Sustav za podršku u sklopu Integriranog knjižničnog sustava}

Knjižnični program Aleph predstavlja Integrirani knjižnični sustav ${ }^{26}$ koji se sastoji od nekoliko osnovnih modula, kao što su npr. modul Nabava, modul Katalogizacija, modul Cirkulacija, grafičko sučelje za pretraživanje, Web OPAC. Knjižnični program Aleph kroz različite module podržava sve segmente knjižničnog poslovanja te važne međunarodne protokole i standarde.

Sustav za podršku ustanovljen je 2011. godine s ciljem pružanja tehničke podrške svim knjižnicama u Integriranom knjižničnom sustavu, Nacionalnoj i sveučilišnoj knjižnici u Zagrebu i visokoškolskim i znanstvenim knjižnicama Republike Hrvatske, sveukupno 43 knjižnice. Sustav se temelji na primjeni zajedničkog integriranog knjižničnog sustava Aleph, formata MARC 21, središnje normativne kontrole, nacionalnog predmetnog sustava i tezaurusa.

\subsubsection{Servisi u knjižničnom programu Aleph}

Kvaliteta podataka u modulu Katalogizacija, u dijelu predmetne katalogizacije, kontrolira se kroz brojne servise. Servisi su skup naredbi i alata za upravljanje i izmjenu velike količine zapisa (npr. alati za globalno ažuriranje zapisa). Servisi također sadržavaju i alate koji generiraju izvještaje, procedure katalogizacije, kreiranje indeksa itd.

Servise pokreću sistemski knjižničari unutar Sustava za podršku Integriranog knjižničnog sustava po potrebi i u dogovoru s ključnim knjižničarima.

26 Integrirani knjižnični sustav predstavlja zajednički sustav NSK-a i knjižnica iz sustava znanosti i visokog obrazovanja Republike Hrvatske koje rade u knjižničnom programu Aleph. 
Servis $U R L$ Check provjerava valjanost vanjske poveznice URL normativnih zapisa u polju 856 - Elektronička lokacija i pristup, potpolje \$u. Neispravne vanjske poveznice znače netočne elektroničke dopunske informacije o entitetu za koji je zapis kreiran.

\section{Primjer 12. 150 \$a Fizika tla}

856노 $\$$ uttp://www.enciklopedija.hr/natuknica.aspx?id=88

\$y Hrvatska enciklopedija (Agroekologija)

Zbog necjelovitog citiranja URL-a došlo je do ispuštanja jednog broja u adresi, pa bi poveznica dovela korisnika do krive natuknice. Točan URL za konkretan primjer bio bi http://www.enciklopedija.hr/natuknica.aspx?id=885.

Funkcija koja se koristi za sređivanje i provjeru kataložnih zapisa jest Fix and Check Catalog records, a pokreće se učitavanjem kataložnih zapisa.

Od velike su koristi za održavanje kataloga i razna izvješća. Ona pomažu kada se trebaju dobiti podaci o npr. nepovezanim odrednicama u bazi, normativnoj ili bibliografskoj. To su odrednice koje „vise“ i u tom slučaju treba se pokrenuti servis Delete Unlinked Headings koji će ih izbrisati.

Pomoć u kontroli normativne baze odrednica pruža i servis List Unauthorized Headings. Pomoću njega izrađuje se popis odrednica u bibliografskoj bazi koje nisu validirane, odnosno povezane s odrednicama u normativnoj bazi.

Slične odrednice u bazi koje se minimalno razlikuju (jedno slovo, jednina/ množina ili interpunkcija, npr. radi se o istim odrednicama, ali je jedna u inverziji, a druga u pridjevskom obliku) mogu se otkriti putem servisa Detect Similar Headings.

Servis List Headings Having Multiple Document Records izrađuje popis odrednica koje se nalaze u više normativnih zapisa, npr. otkriva istu odrednicu ponekad upisanu u polje $1 \mathrm{XX}$, a ponekad u polje $4 \mathrm{XX}$. U svakom slučaju, to je vrlo koristan servis jer u skladu s pravilima mora postojati jedna i jedinstvena odrednica u normativnom zapisu.

Jedan od ključnih servisa Alepha koji provodi Sustav za podršku jest servis Globalno ažuriranje ili Globalne promjene (Global changes). Servis omogućava unos promjena u svim kataložnim zapisima u skladu s kriterijima odabira. Moguće je odabrati da se zapisi ne mijenjaju do nekog trenutka i da se dobije samo izvještaj o njima prema kriterijima u upitu. Zahtjev za globalne promjene predmetnih odrednica šalje ključni knjižničar putem prijavnice na Sustav za podršku (slika 4). Njegova je odgovornost prilikom odabira kriterija za upit velika jer to zahtijeva odlično poznavanje formata MARC i pretraživanje kataloga.

Trajanje cijelog postupka ovisit će o složenosti upita. Ključni knjižničar šalje prijavnicu s detaljnim opisom izmjene koja se očekuje, ukupnim brojem bibliografskih zapisa za izmjenu i definiranim MARC-poljima i potpoljima za predmet- 
nu odrednicu. U suradnji sa sistemskim knjižničarima i redaktorom bibliografske baze rješavaju se globalna ažuriranja.

Prije slanja prijavnice prethodi detaljna analiza stanja u bibliografskoj bazi. Ustanovi se da postoji određeni broj zapisa u kojima se treba promijeniti oblik odrednice sukladno obliku odrednice u normativnoj bazi. Dogovor je sa sistemskim knjižničarima da se globalna izmjena neće raditi ukoliko je pojavnost zapisa ispod dvadeset. Te zapise ispravljaju ručno sami katalogizatori i/ili redaktori.

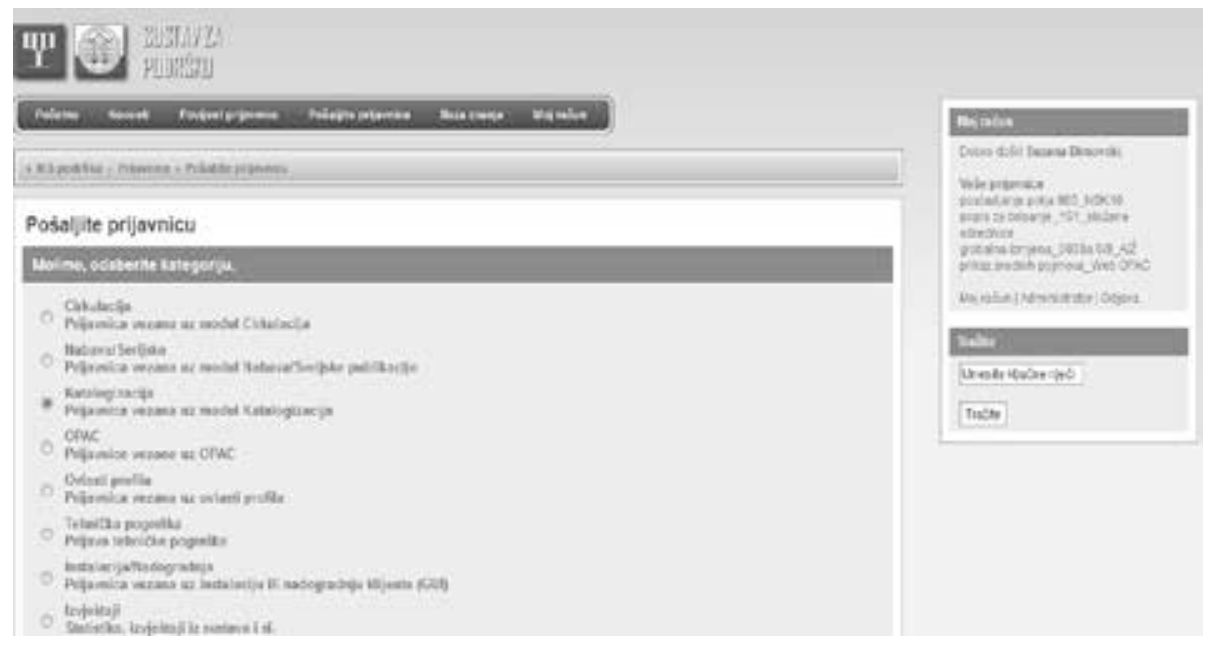

Slika 4. Slanje prijavnice u modulu Katalogizacija

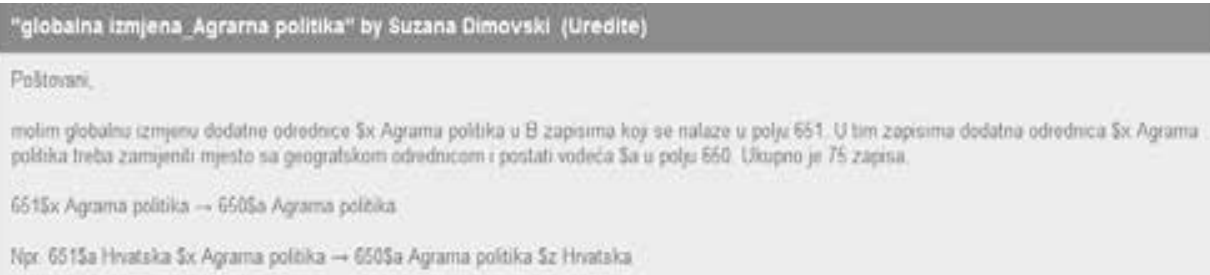

Slika 5. Postavljanje upita Sustavu za podršku

Postavljanje upita i slanje prijavnice u Sustav za podršku sljedeći je korak, nakon čega slijedi komunikacija vezana uz predmet (slika 5).

Slijedi komunikacija sa sistemskim knjižničarima o eventualnim dodatnim pitanjima, a potom provjera podataka u datotekama prije puštanja servisa Globalno ažuriranje na bibliografsku bazu, kao i provjera podataka nakon izvršene radnje u bibliografskoj bazi. U normativnom zapisu izmijenjene odrednice, u polju 952 
dodaje se interna napomena 0 bib. zapisa za izmjenu. Kada je prijavnica riješena, zatvara ju ključni ili sistemski knjižničar (slika 6).

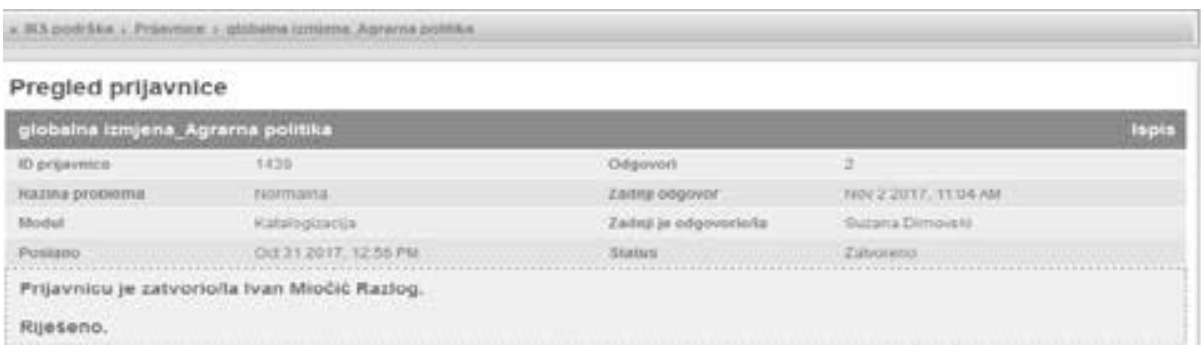

Slika 6. Zatvaranje i status prijavnice

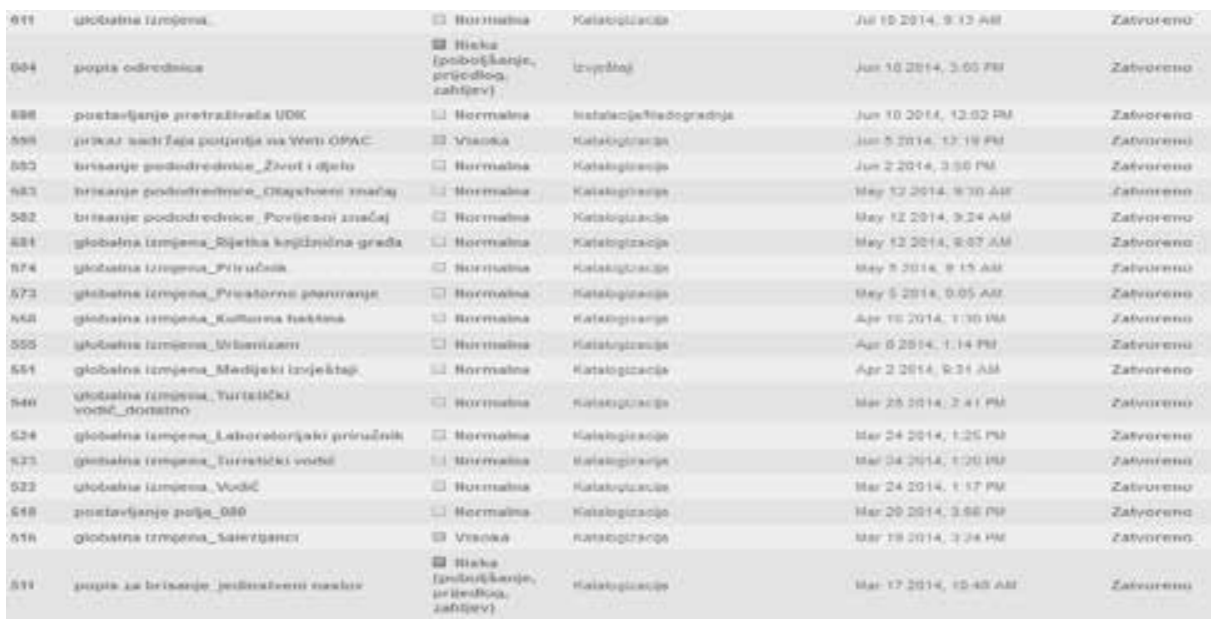

Slika 7. Dio popisa prijavnica poslanih na Sustav za podršku

Statistika svih poslanih prijavnica i njihov status dostupni su u svako doba ključnim i sistemskim knjižničarima (slika 7).

\subsubsection{Mjesečni popisi}

Mjesečno se izrađuju popisi novih, dopunjenih, izmijenjenih i obrisanih normativnih zapisa kao dio dokumentacije u svrhu održavanja predmetnog kataloga (interni popisi Nacionalne i sveučilišne knjižnice u Zagrebu). Ti popisi dobivaju se slanjem prijavnice putem Sustava za podršku (vidi tablicu 1). Navedene popise pregledavaju i odobravaju redaktori predmetnog kataloga koji prema potrebi mogu mijenjati zapise i odobravati ih kao validne za korištenje. 
Tablica 1. Isječak iz tablice dobivene SQL-upitom

\begin{tabular}{|c|c|c|c|c|c|}
\hline \multicolumn{2}{|c|}{ Predmet prijavnice } & \multirow{2}{*}{ Razina } & \multirow{2}{*}{$\begin{array}{l}\text { Modul } \\
\text { kithegeras }\end{array}$} & \multirow{2}{*}{$\begin{array}{l}\text { Poslano } \\
\text { |lity 92015,921 aly }\end{array}$} & \multirow{2}{*}{$\begin{array}{l}\text { Status } \\
\text { Zathereno }\end{array}$} \\
\hline 1500 & 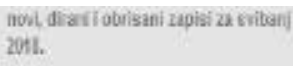 & & & & \\
\hline 150 & & \multicolumn{2}{|l|}{000695235} & \multicolumn{2}{|c|}{ \$\$aŠkolstvo\$ \$xDecentralizacija } \\
\hline 150 & & \multicolumn{2}{|l|}{000695250} & \multicolumn{2}{|c|}{$\$ \$ a$ aOsobnost i kultura } \\
\hline 150 & & \multicolumn{2}{|c|}{000695294} & \multicolumn{2}{|c|}{ \$\$aPrivatne sigurnosne službe } \\
\hline 180 & & \multicolumn{2}{|l|}{000695678} & \multicolumn{2}{|c|}{ \$ \$xUčinak vlažnosti tla } \\
\hline 180 & & \multicolumn{2}{|l|}{000695680} & \multicolumn{2}{|l|}{ \$ \$xUčinak sulfata } \\
\hline
\end{tabular}

\subsubsection{Redaktori predmetnog kataloga}

Oni odlučuju o načinu ispravljanja većeg broja zapisa, pregledavaju i odobravaju odrednice koje se nalaze u mjesečnim popisima kao validne za korištenje i po potrebi ih revidiraju, rješavaju složene slučajeve ispravaka ili ukidanja postojećih odrednica.

\subsubsection{Podaci dobiveni SQL-upitom}

Jedan od alata za provedbu sustavnog redakcijskog nadzora jest SQL. Programski jezik SQL (Structured Query Language) standardni je jezik za upravljanje relacijskim bazama podataka. Sastavljen je od naredbi koje omogućavaju uvoz i izvoz podataka iz baze, razne tablice, kompleksne upite, izvještaje itd. To je koristan alat za dohvaćanje i upravljanje podacima, npr. dohvaćanje zapisa iz bibliografske baze gdje dodatne odrednice nisu normirane u normativnoj bazi (vidi tablicu 2). Dobiveni tablični popis pregledava ključni knjižničar i šalje ga na ispravak katalogizatorima u normativnoj i/ili bibliografskoj bazi zajedno s uputama za ispravak. Katalogizatori prema svom popisu u tablici izvršavaju odgovarajuće izmjene u zapisima.

Tablica 2. Isječak iz tablice dobivene SQL-upitom

\begin{tabular}{|c|c|c|c|c|c|c|c|}
\hline 000473061 & 6507 & $? 2$ & $\begin{array}{l}\text { \$\$aEvangeli- } \\
\text { zacija } \\
\$ \$ 2 n k s p s\end{array}$ & CONV & $\mathrm{am}$ & $\begin{array}{c}\text { \$\$žžalo0302\$\$fvhop0303 } \\
\text { \$\$cbpa0040901 } \\
\text { \$\$iAMAr1510\$ \$cksio151014 }\end{array}$ & \$\$pCRO\$\$rHRB1988 \\
\hline 000473277 & 6507 & $? 2$ & $\begin{array}{c}\text { \$\$aPrirodni } \\
\text { plin\$\$xHidra- } \\
\text { ti\$\$2nsps }\end{array}$ & CONV & aа & $\begin{array}{c}\text { \$atrio0302\$\$atomp0304 } \\
\$ \$ c l b a 0040929 \$ \$ c b p- \\
\text { kp050420 } \\
\$ \$ c \text { cmzop160531 }\end{array}$ & $\$ \$ p C R 0 \$ \$ z B 3 / 02$ \\
\hline
\end{tabular}


Svi pobrojani načini redakcijskog nadzora i sustavne kontrole predmetnih odrednica stvaraju stabilan sustav i utječu na kvalitetu normativne i bibliografske baze podataka.

\section{Zaključak}

Kvalitetna normativna baza u Nacionalnoj i sveučilišnoj knjižnici omogućit će izradu kvalitetnih bibliografskih zapisa prilikom predmetne obrade građe. Time se postiže stabilan predmetni katalog i konzistentnost baze. Korisnicima javno dostupnih kataloga omogućen je jednostavniji pristup knjižničnoj građi prilikom pretraživanja, uz dobivanje relevantnih rezultata. Osuvremenjeni i kvalitetni bibliografski i normativni zapisi zadovoljavaju potrebu korisnika da u što kraćem roku dođu do potrebne literature putem predmeta. To ovisi o mnogim parametrima: organizaciji radnog procesa sadržajne obrade, dostupnim tehnologijama, programskoj opremi, ali i znanju i iskustvu katalogizatora, ključnog i sistemskog knjižničara, redaktora baze i sustava za podršku.

Sustavnim redakcijskim nadzorom nad predmetnim odrednicama kontrolira se njihova kvaliteta. To podrazumijeva otkrivanje sintaktičkih, semantičkih te pravopisnih i tipografskih pogreški. Prema međunarodnim preporukama treba se povećati učinkovitost bibliografske i normativne produkcije. Održavanje kvalitete zapisa i dosljedna primjena MARC-formata omogućava razmjenu podataka u bibliografskom okruženju. Trenutno je razmjena predmetnih odrednica između Nacionalne i sveučilišne knjižnice u Zagrebu i ostalih knjižnica na nacionalnoj razini otežana zbog nepostojanja jedinstvenog pravilnika za rad.

Predmetni podaci koji se nalaze u normativnoj bazi Nacionalne i sveučilišne knjižnice u Zagrebu, a temelje se na predmetnom sustavu Kongresne knjižnice, kao nadzirani rječnik još se uvijek premalo koriste u bibliografskim zapisima od strane ostalih knjižnica u integriranom knjižničnom sustavu. Novim pravilnikom to bi se stanje izmijenilo, postojao bi jedinstven predmetni sustav, a katalogizatori bi slijedili ista pravila i napomene o korištenju predmetnih odrednica pri izradi složenih predmetnih odrednica. Postigla bi se veća ekonomičnost, protočnost i povezanost podataka.

Cilj je u budućnosti postići to da se predmetni podaci povezuju u okruženju semantičkog weba kao strojno čitljivi, otvoreni i povezani podaci. Povezani podaci ne zamjenjuju knjižnične kataloge, nego predstavljaju njihovu nadgradnju. ${ }^{27}$

Zato je integracija knjižničnih kataloga važan preduvjet u ostvarenju tog cilja. Izgradnja dvojezičnog hrvatsko-engleskog kontroliranog rječnika predmetnih

27 Farago; F.; B. Bosančić; B. Badurina. Povezani podaci i knjižnice. // Vjesnik bibliotekara Hrvatske 56, 4 (2013), str. 35. [citirano: 2018-03-25]. Dostupno na: https://www.hkdrustvo.hr/ vjesnik-bibliotekara-hrvatske/index.php/vbh/article/view/138/133. 
odrednica, kompatibilnog s predmetnim sustavima na međunarodnoj razini, od iznimne je važnosti. Zaključno, možemo reći da izrada kvalitetnih predmetnih zapisa, konzistentnost kataloga, trajna edukacija katalogizatora u predmetnoj obradi $i$ točna primjena procedure rada u predmetnoj obradi doprinose suvremenoj razmjeni podataka u knjižničnom okruženju.

\section{LITERATURA}

Badovinac, B. Izhodišča za proučevanje kakovosti podatkov v bibliografskih in normativnih zapisih: kakovost podatkov v kontekstu in raziskovalne usmeritvev katalogizaciji. // Knjižnica 61, 1-2 (2017), 119-154.

Exlibris. Aleph 23 user guide - authorities [citirano: 2018-05-17]. Dostupno na: https:// knowledge.exlibrisgroup.com/Aleph/Product_Documentation/01_Version_23.

Farago; F.; B. Bosančić; B. Badurina. Povezani podaci i knjižnice. // Vjesnik Bibliotekara Hrvatske 56, 4 (2013), 25-52. [citirano: 2018-03-25]. Dostupno na: https://www. hkdrustvo.hr/vjesnik-bibliotekara-hrvatske/index.php/vbh/article/view/138/133.

Graham, P. S. Quality in cataloging: making distinctions. // Journal of Academic Librarianship 16, 4 (1990), 213-218. [citirano: 2018-03-24]. Dostupno na: https://eric. ed.gov/?id=EJ416995.

Gregor D.; C. Mandel. Cataloging must change! // Library Journal 116, 6(1991), 42-47. [citirano: 2018-03-24]. Dostupno na: https://eric.ed.gov/?id=EJ424864.

Hider, P.; K. Tan. Constructing record quality measures based on catalog use. // Cataloging and Classification Quarterly, 46, 4 (2008), 338-361.

Izjava o Međunarodnim kataložnim načelima / prevela Mirna Willer. 2009. [citirano: 2018-06-11]. Dostupno na: https://www.ifla.org/files/assets/cataloguing/icp/ icp_2009-hr.pdf.

Izrada predmetnog kataloga u Nacionalnoj i sveučilišnoj knjižnici u Zagrebu. Zagreb: Nacionalna i sveučilišna knjižnica u Zagrebu, 2005. (interni dokument).

Kanič, I. Normativna kontrola in normativne datoteke. // Knjižnica 34, 1/2, (1990), 1-7. [citirano: 2018-03-24]. Dostupno na: https://www.dlib.si/stream/URN:NBN:SI:DOC-OREGQFZ3/cf06cdd7-b3f6-41c2-a685-05da77ea899d/PDF.

Library of Congress Subject Headings. 29th ed. Washington, D.C. : Library of Congress, Cataloging Distribution Service, 2006. [citirano: 2018-06-11]. Dostupno i na: http://id.loc.gov/authorities/subjects.html.

Mugridge, R. L.;K. A. Furniss. Education for authority control: whose responsibility is it? // Cataloging \& Classification Quarterly 34, 1/2 (2002), 231-241. DOI: https:// doi.org/10.1300/J104v34n01_14. 
Osnove projektiranja baza podataka: priručnik za polaznike. Zagreb: Sveučilišni računalni centar, 2010. [citirano: 2018-05-18]. Dostupno na: http://www.srce.unizg.hr/ files/srce/docs/edu/osnovni-tecajevi/d310_polaznik.pdf.

Strategija Nacionalne i sveučilišne knjižnice u Zagrebu: 2016.-2020. [citirano: 201806-11]. Dostupno na: http://www.nsk.hr/wp-content/uploads/2012/01/Strategija-NSK-2016.-2020..pdf.

Subject Headings manual (SHM ) [citirano: 2018-3-24]. Dostupno na: https://www.loc. gov/aba/publications/FreeSHM/freeshmabout.html.

Sustav za podršku Nacionalne i sveučilišne knjižnice u Zagrebu. [citirano: 2018-06-11]. Dostupno na: http://iks.nsk.hr/podrska.

Štrbac, D.; M. Vujić. Pravilnik za predmetni katalog. Zagreb: Knjižnice grada Zagreba, 2004.

Thomas, S. E. Quality in bibliographic control. // Library Trends 44, 3 (1996), 491505. [citirano: 2018-03-24]. Dostupno na: https://www.ideals.illinois.edu/bitstream/ handle/2142/8039/librarytrendsv44i3d_opt.pdf?sequence $=1$.

Vujić, M. Pregledni zapisi u formatu MARC 21: upute za katalogizaciju. Zagreb: Nacionalna i sveučilišna knjižnica u Zagrebu, 2011. 